\title{
Maximum Credible Uranium-235 Release from 211-H to the ETF
}

by

T. G. Campbell

E. I. du Pont de Nemours and Company

Savannah River Site

Aiken, South Carolina 29808

\section{INFORMATION ONLY}

\section{DISCLAIMER}

This report was prepared as an account of work sponsored by an agency of the United States Government. Neither the United States Gnvernment nor any agency thereof, nor any of their employees, makes any warranty, express or implied, or assumes any legal liability or responsibility for the accuracy, completeness, or usefulness of any information, apparatus, product, or process disclosed, or represents that its use would not infringe privately owned rights. Reference herein to any specific commercial product, process, or service by trade name, trademark, manufacturer, or otherwise does not necessarily constitute or imply its endorsement, recommendation, or favoring by the United States Government or any agency thereof. The views and opinions of authors expressed herein do not necessarily state or reflect those of the United States Government or any agency thereof.
RECEIVED

OCT 221998

OSTI

\section{DOE Contract No.}

This paper was prepared in connection with work done under the above contract number with the U.S. Department of Energy. By acceptance of this paper, the publisher and/or recipient acknowledges the U. S. Government's right to retain a nonexclusive, royalty-free license in and to any copyright covering this paper, along with the right to reproduce and to authorize others to reproduce all or part of the copyrighted paper.

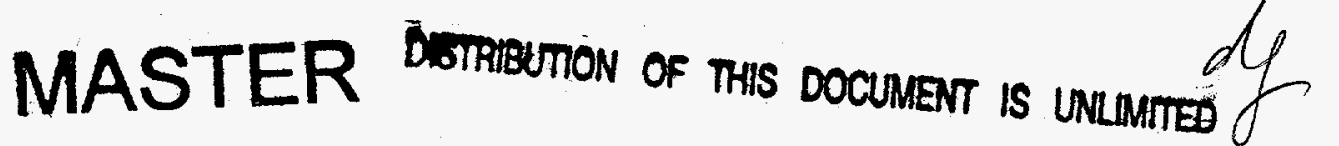




\section{DISCLAIMER}

Portions of this document may be illegible in electronic image products. Images are produced from the best available original document. 
OSR 3-A *

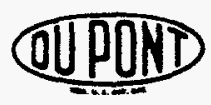

\section{INTER-OFFICE MEMORANDUM}

Savannah River Plant

September 20, 1988
DPSP-88-272-106

Keywords: ETF, 211-H, Release, Criticality

Retention Time: Permanent

TO:

E. W. MANCI, 703-H

FROM: T. G. CAMPBELL, 221-H

\section{MAXIMUM CREDIBLE URANTUM-235 RETEASE FROM 21I-H TO THE ETF}

\section{Introduction and summary}

The Effluent Treatment Facility (ETF) criticality review identifies two potential scenarios for criticality:

- An instantaneous release of a significant quantity of fissile material frcm a process upset.

- A gradual accumulation of fissile material in process vessels. 1

The potential for an instantaneous release from $211-\mathrm{H}$ will be eliminated by the installation of a muclear safety blank as recommended in the criticality review.

With the nuclear safety blank installed, the only mechanism for introducing a gradual accumulation of uranium to the ETF from 211-H will be via Acid Recovery Unit (ARU) and General Purpose (GP) evaporator overheads. This study has determined that the maximm credible anmual release of uranium-235 to the ETF from these sources is 106 grams.

\section{Discussion}

\section{Basis}

To perform this study the following assumptions were made:

- Anmual H-Canyon production of $10,000 \mathrm{~kg}$ uranium.

- Nuclear Safety blank installed as recommended by ETF criticality review. (OnlY ARU and GP overheads transferred to the ETF from 211-H.) 
E. W. MANCI

Page 2

September 20, 1988

- Evaporator decontamination factor (DF) for uranium of $10^{4}$. (U DF reported in DP-500 for batch evaporators is $10^{6}$. GP evaporator DF for nonvolatiles reported as $\left.10^{5} \cdot\right)^{2}$

- ARU uranium DF of $10^{4}$.

$\underline{A R U}$

The ARU (Figure 1) is a ten tray distillation colum that recovers $50 \%$ nitric acid from H-Canyon evaporator overheads. The ARU overheads, at a pH of 2-3, are sampled for alpha and beta-gamma activity and then transferred to the seepage basin (ETF), if within limits. Supplying overheads to the ARU are the ICU evaporator, head end and high activity waste (HAW) evaporators, low activity waste (LAW) evaporators, the $2 \mathrm{BP}$ evaporator, and the rerun evaporator. Any uranium entering the ARU system must be contained in these overhead streams. The 10U evaporator concentrates the uranium product stream from first cycle and has the highest potential to produce overheads containing uranium. The rerun evaporator concentrates sump solutions which often contain uranium. The LAW evaporators concentrate large volumes of solvent extraction waste solution, which contain low levels of uranium. HAW evaporation is a two stage process in which the overheads from the first stage are evaporated again to improve decontamination. The 2BP evaporator concentrates second neptunium cycle product which contains essentially no uranium.

\section{ICU Evaporator}

The 1CU evaporator concentrates the uranium product stream from first cycle to about $6 \mathrm{gU} / \mathrm{l}$; a typical batch contains about $15 \mathrm{~kg}$ of total uranium. For $10,000 \mathrm{~kg} U$ annual proctuction, $66710 \mathrm{~d}$ evaporator batches are required. Assuming a U DF of $10^{4}$ in the evaporator, the $U$ concentration in the overheads would be $0.0006 \mathrm{gU} / 1$. Since a typical 1CU evaporator batch produces 1211 liters of overheads ${ }^{3}$, the total amount of uranium sent to the ARU per year from the 1 CU evaporator is 485 grams.

\section{IAW Evaporators}

The LAW evaporators process waste streams from second $\mathrm{Np}$ cycle and second U cycle, as well as other miscellaneous low level wastes such as decontamination waste and HB-Iine waste. These wastes normally contain only trace quantities of uranium; however, for the purposes of this study, the evaporators were assumed to always contain the maximm amount of uranium that can be discarded to waste (50 grams). According to the HM process flowsheet ${ }^{3}$, the IAW evaporators produce about 2050 liters of overheads per $\mathrm{kg}$ of uranium processed, or $2.05 \mathrm{E} 7$ liters annually for $10,000 \mathrm{~kg} \mathrm{U}$ productjon. Assuming an average evaporator volume of 3600 liters and a U DF of $10^{4}$, the overheads $U$ concentration would be $1.4 \mathrm{E}-6 \mathrm{gU} / \mathrm{l}$. The total amount of uranium annually in the overheads would be 30 grams. 
E. W. MANCI

Page 3

September 20, 1988

\section{Rerun Evaporator}

The rerun evaporator concentrates H-Canyon sump solutions containing recoverable amounts of uranium. Typical sump solution batches contain about 1750 liters and the maximm mumber of sump batches expected per month is 20 . If all of these batches are assumed to contain recoverable amounts of uranium, the total volume evaporated per year is 420,000 liters. Making the conservative assumption that the evaporator always contains $5 \mathrm{gU} / 1$, the overheads would contain $0.0005 \mathrm{gU} / 1$. Assuming 400,000 liters of overheads are produced, the total amount of uranium contained anmually in the rerun overheads is 200 grams.

\section{Head End and HAW Evaporators}

The head end evaporator concentrates dissolver solution to prepare feed for first cycle. The uranium concentration in the head end evaporator is about $6 \mathrm{gU} / \mathrm{l}$ and the amount of uranium in the overheads should be similar to that found in the 10u overheads. However, the head end evaporator overheads are reevaporated in the HAW second stage evaporator for further DF. The HAW evaporators process the waste from the first cycle of solvent extraction. Because of the two stages of evaporation, no uranium is assumed to be in the overheads sent to the ARU from the HAW system, which includes the head end evaporator overheads.

\section{ARU Sunmary}

As discussed above, the calculated anmual uranium imput to the ARU is as follows:

Source

ICU Evaporator

IAW Evaporators

Rerun Evaporator

Total
Uranium, g

485

30

$\underline{200}$

715

Assuming a U DF in the ARU of $10^{4}$, the amount of total uranium expected to be contained anmually in the ARU overheads is 0.07 grams.

\section{General Purpose Evaporator}

The GP evaporator (Figure 2) receives wastes from 211-H basins and aprons, canyon floor drains, cold feed and third level tank drains, hot and warm gang valve corridor catch tanks, and target cleaning solution and deionizer regeneration solution from RBOF. These wastes are neutralized to a pH of 8 or greater and then fed continuously to the GP evaporator until the evaporator bottoms reach a density endpoint. The concentrated bottoms are then transferred to a concentrate hold tank, sampled, pH adjusted if necessary, and then transferred to the waste tank farm. The GP overheads, usually pH 9 or greater, are sampled for alpha and beta-gamma and then sent to seepage (ETF), if within specifications. 
E. W. MANCI

Page 4

September 20, 1988

Before the GP evaporator feed is neutralized, it is sampled for acid and uranium. There is a muclear safety control that requires the acidity to be greater than $0.01 \mathrm{~N}$ to assure representative uranium analyses. If the acidity is low, acid is added until the minimm acid limit is met. Another muclear safety control requires the GP evaporator system to be flushed with acid after a total of 700 grams of U-235 have been fed to the system. There is also a nuclear safety control which limits the amount of U-235 that can be fed to any individual batch to 250 grams.

Accountability records show that from 1981 to 1987 the average amount of uranium processed through the GP evaporator system each year was 1067 grams. The highest yearly total was 1983 when 2116 grams were processed. Using this historical data and assuming a uranium DF of $10^{4}$, less than one gram of uranium per year would be expected in GP evaporator overheads. However, for this study, the following conservative assumptions are made:

- Evaporator contains NSC max 250 grams U-235 at all times.

- Feed 16 hours per day, allow 8 hours for sample analyses.

- Operate 292 days per year (80\% of the time).

- Feed rate of $5000 \mathrm{lbs} /$ hour.

o Operating volume of 2500 liters.

Using these assumptions, the GP evaporator will produce about 1.06E7 liters of overheads per year with a uranium concentration of $0.00001 \mathrm{~g} / 1$. This gives $a$ total of 106 grams of U-235 released to the ETF each year.

\section{Evaporator Upsets}

Operating upsets, which reduce the evaporator DF by causing excessive entraiment of nonvolatiles, are uncommon but do occasionally occur during evaporator operations. Canyon batch evaporators are equipped with column differential pressure (DP) instruments which easily detect these upsets. In addition, the evaporator steam supply is interlocked off if a high colum DP is detected. Batch evaporators are also equipped with three bubble cap deentraiment trays which minimize the effects of minor upsets. All evaporator overheads are sampled and are recycled if analyses indicate an upset resulting in poor DF.

Severe upsets (burps) can result in some portion of the evaporator contents being expelled into the condensed overheads. Burps have the greatest tendency to occur in the head end evaporator and the low activity waste evaporators. The material processed in these evaporators has a tendency to foam, which is often the cause of burps. Operating experience indicates that a frequency of one evaporator burp per year per evaporator is conservative. The observed frequency of burps in some evaporators (ICU and second stage HAW) is much less. No more than 5 to $6 \%$ of an evaporator's contents has been observed to be 
E. W. MANCI

Page 5

September 20, 1988

expelled during a severe burp. For the lov evaporator, which typically contains about $15 \mathrm{~kg}$ uranium, 1500 grams of uranium would result in the overheads, assuming a conservative $10 \%$ of the evaporator contents were expelled during a burp. In the unlikely event that the burp is undetected by either instrumentation or sample analysis, and is transferred to the ARU, only 0.15 grams of uranium would result in the ARU overheads, assuming an ARU DF of $10^{4}$. Based on this evaluation, the effect of canyon batch evaporator upsets on releases of uranium to the ETF is considered to be insignificant.

The ARU and GP evaporators have no history of upsets or burps that could reduce the DF of nonvolatiles such as uranium. The ARU is a ten bubble cap tray distillation colum and it is very unlikely that an upset could occur that would result in an excessive amount of uranium in the overheads. The GP evaporator is very different from the canyon batch evaporators. Canyon batch evaporators are heated by steam coils in the evaporator pot. The GP evaporator has no coils; the feed is continuously pumped through a preheater and into the evaporator where it flashes into vapor and bottoms. The bottoms are continuously recycled through the preheater and back to the evaporator until the endpoint density is reached. The evaporator is operated under vacurm (200 $\mathrm{nmHg}$ ) and has four bubble cap trays for deentrairment. Since the evaporator feed is heated externally, there is really no mechanism to produce the types of upsets or burps sometimes seen in canyon batch evaporators.

\section{Conclusions}

This study indicates a maximum credible release to the ETF from the 211-H facility of 106 grams of U-235, essentially all from the GP evaporator. The assumption that the GP evaporator contains 250 grams U-235 at all times is highly conservative and does not in any way represent current (normal) operation. This "worst case" assumption results in a calculated maximum credible release that is more than 100 times that expected from normal operation.

As stated in the ETF criticality review, historically 34 grams of U-235 has been released to the seepage basin anmually. Eliminating the conservatism used in assumptions for the GP evaporator, this study predicts annual releases of less than 1 gram of U-235 from ARU and GP evaporator overheads. This apparent discrepancy is due to the changes, which are the basis for this study, that will be made in 211-H before ETF startup. A nuclear safety blank will be installed in 211-H that eliminates the transfer of basins and tank aprons directly to the ETF. All of this material, which could contain some uranium, will be evaporated in the GP evaporator, and only the overheads released to the ETF. The majority of the uranium released to the seepage basin in the past probably came from these basins and tank aprons that were sent directly to seepage without evaporation. 
E. W. MANCI

Page 6

September 20, 1988

\section{References}

1. N. R. Davis and E. W. Manci to T. A. Reilly, et al., "Effluent Treatment Facility (ETF) Criticality Review, Revision 1", September 14, 1988.

2. DP-500, "Processing of Irradiated Natural Uranium at Savannah River", August 1960.

3. R. L. Heltz to J. F. Ortaldo, DPSPU-87-272-1, "HM Process Flowsheet Spreadsheet", January 9, 1987.

/tgc

Att

CC: J. F. Ortaldo, 703-A

M. F. Sujka, 703-A

C. B. Jones, ETF-3

J. K. Brown, 703-H

J. E. Dickenson, 703-H

V. G. Dickert, 221-H

T. A. Reilly, 707-H

P. A. Croll, 705-H

G. F. Molen, 773-4IA

E. D. Strother, 703-F

R. C. Marozas, 247-F

N. R. Davis, 703-H

C. R. Goergen, 221-H

T. F. Severynse, 221-H

D. F. Brown, 703-H

T. Y. Gill, 221-H

Central Files, 703-A 


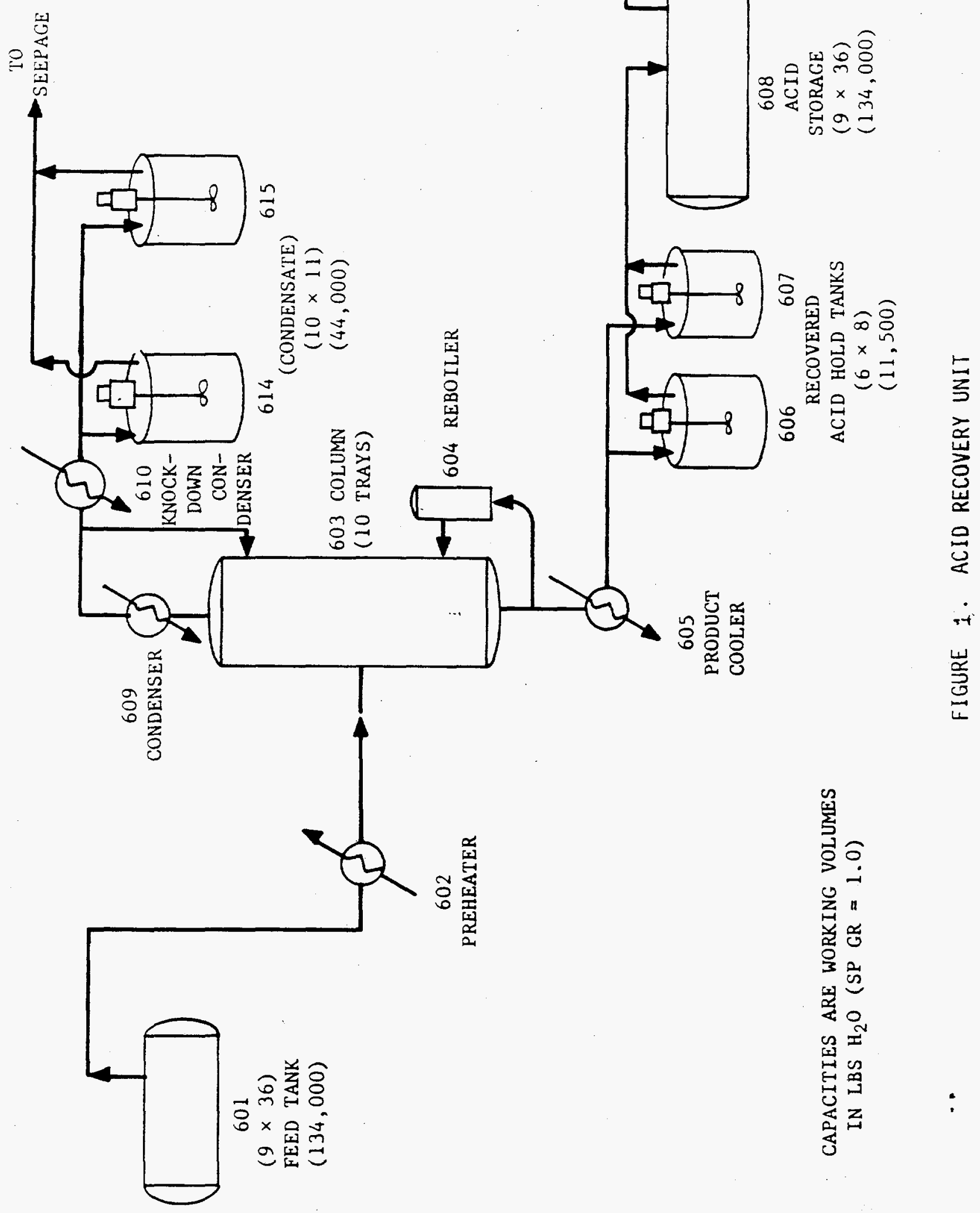




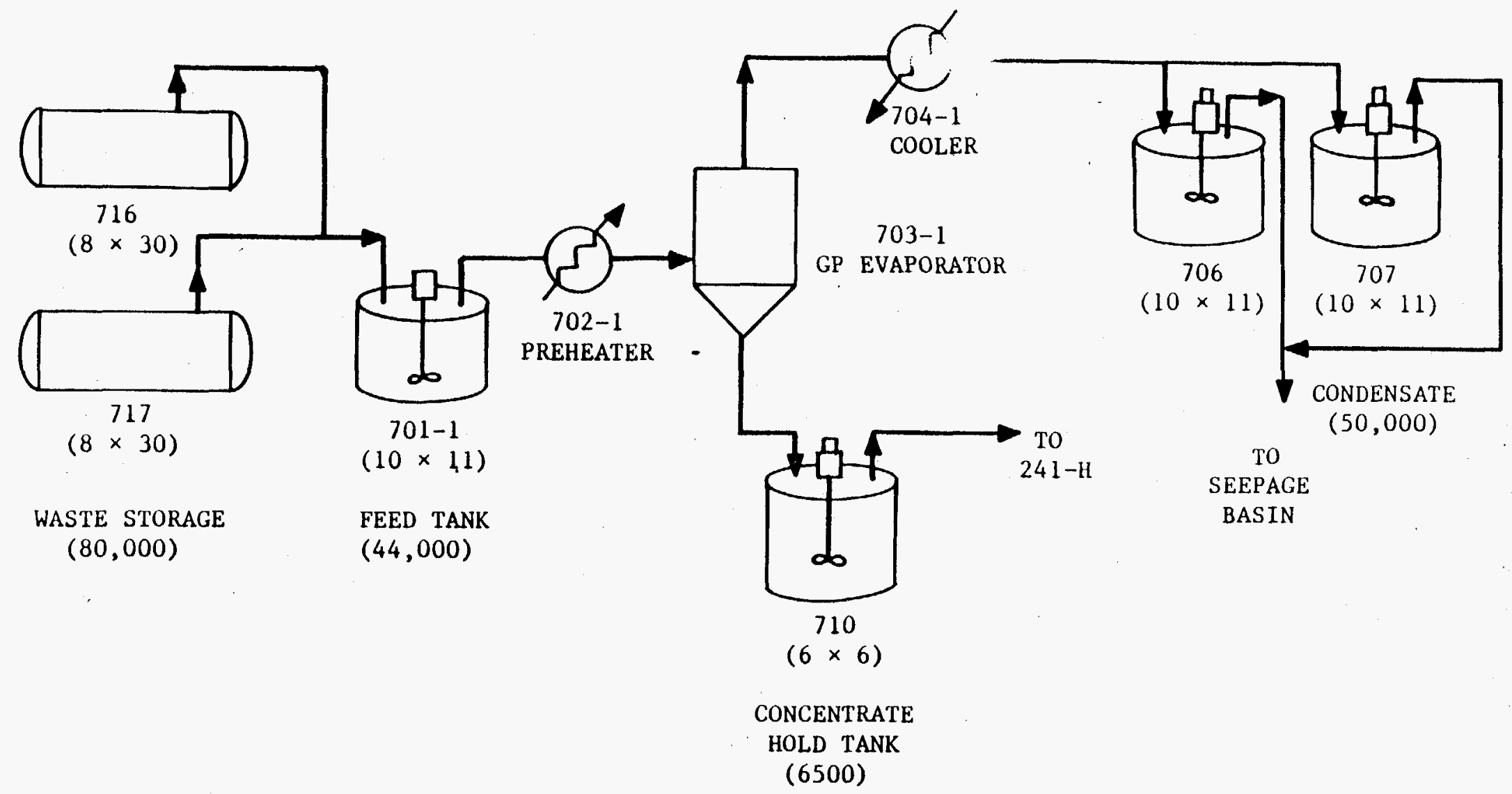

[NOTE: CAPACITIES ARE WORKING VOLUMES IN LBS $\mathrm{H}_{2} \mathrm{O}(\mathrm{sp} \mathrm{gr} 1.0)$ ]

FIGURE 2 . GP EVAPORATOR 